\title{
Debt Finance and Corporate Performance: Firm Level Empirical
} Evaluation

\author{
Edward Ogbonnia Eleje, (Ph.D) \\ Department of Banking and Finance, \\ Federal University, Wukari, Taraba State, Nigeria \\ Agha Eze Okechukwu \\ Liquidity Management Unit, \\ Treasury Department Keystone Bank Limited, Lagos \\ Eli Oyavuru Chikanele \\ Department of Accounting, \\ Federal University, Wukari, Taraba State, Nigeria
}

\begin{abstract}
Debt finance relevance or financial leverage debate has continued to gain more strength in every discussion of firm capital structure locally and beyond. To some researchers, the application of debt finance could worsen performance of firms and create difficult economic scenario; to others, debt finance could induced better business performance and profitability. It is on the premise of the foregoing arguments that this study sought to investigate the effect of long and short tenured debt on return on assets (ROA) as well as return on equity (ROE) of corporate manufacturing firms in Nigeria. To achieve this, the study relied on firm level data generated from annual report of the National Salt Corporation of Nigeria (NASCON) Plc for a 12-year period (2007-2018). Data were analyzed using time series analysis while the computer-based multivariate linear regression approach aided by Special Package for Social Sciences (SPSS) version 20 was used in the test of the two stated hypotheses. Consistently, the two null hypotheses were sustained since their significant values (sig-value) were greater than 0.05 and their corresponding $t$-values positive. The paper thus concludes that although long and short tenured debt finances may not significantly impact positively on ROA and ROE, long tenured debt could slightly enhance corporate performance. Accordingly, the study recommends among others that, financial managers of corporate manufacturing firms should design optimum capital structure for long and short tenured debt finances considering the varied impact of both on corporate performance.
\end{abstract}

Keywords: Debt Finance, Long term debt, Short term debt, ROA, ROE

\section{INTRODUCTION}

Financial structure argument has continued to generate more heat since the seminal work of Modigliani and Miller (1958). This is due to the indispensability of financial resources to economic growth and development. Efficient allocation of funds is the most vital role of finance managers of corporate firms. It involves decision to commit firms' funds to both long and short term assets. Investment decision is of considerable importance to firms since it tends to determine firms' values by influencing their growth and profitability. The process of investment decision making is often marred by uncertainty and risky scenarios. Firm value at various points in time could therefore manifest fluctuation due to unanticipated changes in product prices, demands, costs, taxes, inflation and other macroeconomic fundamentals (Eleje and Modebe, 2015). Ideally, business managers are risk averse and as such, may not fully control these risks. But to some degree, they can decide the risks that the firm could undertake 
and the one to avoid or transfer. They oftentimes adopt many strategies to ameliorate their firms' risks. They keep several options open and ensure that they are operating flexibilities that may bail them out in difficult times.

Finance managers of corporate firms could aim at reducing their investment risks and magnifying returns via equity trading, a financial process involving the use of debt finance in firm's capital structure to produce gain for the residual owners (Tufano, 1996; and, Jorion, 1995; Eleje, 2009, Yinusa, Ismail, Yulia and Olawale 2019). Debt finance is believed to create financial leverage by reducing costs of financial distress; isolate the effect on firm value and profitability of changes in uncertainty factors such as inflation, and allow managers to focus on improving operating efficiency rather than worrying about changes in factors in which they have no control (Pandey, 2010). In the last few decades, academic scholars in the field of strategic financial engineering and management have attempted to empirically demonstrate the link between debt finance and firm value. Such studies have argued for or against the fact that the success of a corporation depends to a significant extent on the corporation's capital structure strategy (Lucio, 2007; Eleje and Okafor, 2010, Yen, Nhung, Anh \& Huong, 2019).

Despite this plethora of studies, there is still no widely accepted causal relationship between debt finance and corporate performance. The empirical evidence emerging from various studies about the effect of debt fund on corporate performance have so far yielded mixed results that are rather inconclusive and contradictory. As a result, the question of whether debt finance improves or worsens corporate performance is still worthy of further research. Besides, firm level approach which is necessary due to individual firm characteristics have not been adequately explored in developing countries including Nigeria at the moment. There is therefore a major gap in the extant literature on Nigeria which needs to be covered by research. This paper contributes to filling the gap by using firm-level data generated from Nigeria. Specifically, the study sought to investigate the effect of long and short tenured debt on the return on assets (ROA) as well as the return on equity (ROE) of a prototype indigenous Nigerian corporate manufacturing firm, the National Salt Corporation of Nigeria (NASCON) Plc. The study will be relevant to management of corporate firms, foreign and local investors, government, financial analysts, and future researchers.

\section{Debt Finance}

\section{CONCEPTUAL CLARIFICATION}

Debt finance generally connotes cash borrowed from a lender at a fixed or variable rate of interest and with a predetermined maturity date (Pandey, 2006). The principal must be paid back in full at the maturity date although; periodic repayments of principal may be part of the loan arrangement. Debt may take the form of a loan or the sale of bonds; the form itself does not change the principle of the transaction. The lender retains a right to the money lent and may demand it back under conditions specified in the borrowing arrangement. Debt maturity duration and structure could differ. If the specified maturity date falls due within a one year period, it is a short tenured debt. Short-term debts are generally required to finance a substantial portion of a firm's current assets such as cash and inventory. Debt obligation is medium term if it falls due between 5-10 years. But if debt obligation spreads over ten year period, such obligation is a long-term debt. Precisely, loan or borrowing facility is said to be long term if the expected maturity date ranges from 10-30 years and above. The common feature of this type of debt is that the amount involved is usually large. Examples of long tenured loans are term loans and bonds.

Corporate firms can obtain debt capital from a number of different sources including banks, credit unions, finance companies, trade credit, insurance companies, factor companies, and 
leasing companies (Baye and Jansen, 2006). Bonds, stocks and other loan programs provided by the state and federal governments to support manufacturing companies are also good alternative. Bank debt facilities include trade credit, bank overdraft and bank loan.

The use of debt in the capital structure of firms has been perceived to have some shared benefits. The firm profits from debt tax shield effect and financial leverage (Pandey, 2006). The enterprise pays interest to the creditors of the costs, exemption from corporate income tax, while dividends paid to shareholders is deducted from the net profit after corporate income tax; so if interest rate is appropriate, and earnings before interest and tax are more than business interest, then increase in the enterprise debt ratio would increase the tax free income and improves the enterprise market value. Conversely, over borrowing can lead to bankruptcy and financial ruin (Farhan, Iqra, \& Muhammad, 2018; Ndubuisi, Ifechi \& Nweke 2019). High levels of debt will constrain a firm from undertaking projects that are likely to be profitable because of the inability to attract more debt from lending institutions.

\section{Corporate Performance}

Research on firm's performance emanates from organization theory and strategic management (Gavrea, Ilies \& Stegerean, 2011; Hashem, 2015). The notion, 'firm performance' is used to describe the performance of an entity that is an organization which has the legal status of a company. The concept of performance is a controversial issue in finance largely due to its multidimensional meanings. In analyzing firm performance, emphasis should be made in formulating an adequate description of the concept which will uncover the different dimensions upon which it can be evaluated. Webster (1990) defines performance as "what is accomplished." This means the time test of any strategy. Deducing from these analogy, firm performance can be summarized as the outcome of a firm's strategy or an assessment of how well a firm has succeeded in reaching its objectives.

The nature of debt is an important determinant of firm performance. Jaramillo and Schiantarelli (1996) stated that the availability of long-term finance allows manufacturing companies to improve their productivity. If a firm has access to long-term debt finance, it can invest in new capital and equipment which helps to increase productivity. But inability to access long-term finance can force manufacturing companies to use short-term debt to finance long-term projects. Invariably, this will create mismatches of assets and liabilities and depletes working capital which in turn will negatively affect firm operations.

\section{THEORETICAL UNDERPINNING}

The relationship between debt finance and firm performance is suggested in a number of theories some of which are; Capital Structure Irrelevance theory, trade-off theory, signaling theory among others.

\section{Capital Structure Irrelevance Theory}

Capital structure irrelevance theory also referred to as the Modigliani and Miller (1958) theory, provides the fundamental impulse to the study of capital structure problem by showing that under some strong assumptions (an ideal world of pure and perfect competition without taxes) the choice between debt and equity financing has no effect on firm's value. They argue that capital structure is irrelevant to firm's value when assets earnings and future investment opportunities remain constant. The theory says that since financial leverage has no effect neither on the size of operating income nor on the level of business risks, dividing the operating income into two (dividends and interests) should not affect firm value. 


\section{Trade-Off Theory}

The trade-off theory determines an optimal capital structure by adding various market imperfections including taxes, cost of financial distress and agency cost. The theory suggests that firm leverage is driven by three competing forces: (i) taxes (ii) costs of financial distress (bankruptcy costs), and agency conflict. The trade-off theory says that companies have optimal debt-equity ratio, which they determine by trading-off the benefits of debt-against it cost. In the traditional or original form of the model, the major benefit of debt is the tax advantage of interest deductibility (Pandey, 2006). But this traditional view did not take into account that shareholders required rate of return would increase as soon as financial leverage rises. The modern versions of the theory are based on capital market imperfections (taxes, bankruptcy cost, agency cost) and argue that there are trade-off merits and demerits associated with the use of debt capital.

\section{Signaling Theory}

The signaling theory is based on information asymmetries and signaling. The theory argues that firm insiders (managers or shareholders) are equipped with some private information about the characteristics of the firm which is not known by the borrower and that the quality of borrowers can only be ascertained by the borrowers themselves. The information asymmetry between borrowers and lenders induce some adverse selection problems: the impossibility of lenders to price a loan according to the borrower's quality resulting in imperfect pricing which leads to credit rationing (Przepiorka and Berger, 2018). Therefore, "high-quality" borrowers have incentives to show their quality. However, they need to provide this private information by using a credible signal, meaning a signal that cannot be provided by "low-quality" borrowers. Hence, a "good-quality" company can issue more debt than a "lowquality" one, because the issue of debt leads to a higher probability of default due to the debtservicing costs which represent a costly outcome for firm insiders. As a result, debt is a credible signal of the quality of firms and "good-quality" firms are more inclined to issue debt. Thus, this theory suggests that the most performing firms, those having the more profitable investments, ask for more debt.

\section{REVIEW OF EMPIRICAL STUDIES}

Meanwhile, there exist several extant empirical arguments on capital structure. Onimisi (2010) examined the effect of capital structure on the performance of quoted manufacturing firms in Nigeria. Using selected quoted firms and employing simple regression method, the study showed that leverage has significant effect on the performance of quoted manufacturing firms in Nigeria. Similarly, Osuji (2012) investigated the impact of capital structure on financial performance of Nigerian firms. A total sample of thirty (30) non-financial firms listed on the Nigerian Stock Exchange (NSE) was examined over a seven (7) year period, 2004-2010. Panel data for the selected firms were generated and analyzed using ordinary least squares (OLS) estimation. Result revealed that firm's capital structure surrogated by debt ratio has significant negative impact on firm's financial performance.

Akinlo and Asaolu (2012) analyzed data obtained from annual reports and accounts of 66 purposively selected non-financial firms in Nigeria over the period, 1999-2007. Specifically, the study focused on the impact of leverage (debt) on profitability. Pooled ordinary least squares (OLS), fixed and random effects frame works were the methods of data analysis. The result of the study showed that leverage was negatively related to profitability. This suggests that the use of debt by firms in Nigeria decreases profitability. The finding corroborates Lawal, Edwin, Monica, and Adisa (2014) who employed regression technique to consider the impact of some key variables such as return on asset (ROA), return on equity (ROE), total debt (TD), and debt 
capital (DC) on firm performance. The study found that capital structure proxied by TD and debt to equity ratio are negatively related to firm performance.

Zahoor (2015) investigated the effect of financial leverage on the efficiency of firms in Pakistan. Total sample of 154 textile firms in Pakistan were investigated over the period 2006-2011. The study used the ordinary least square technique to detect efficiency of the financial leverage of the firm with regression analysis from pecking order theory point of view. Results indicated that financial leverage has negative association with firms' efficiency. Financial leverage also manifested negative associated with return on assets and equity but market to book ratio showed positive profitable association.

Onoja and Ovayioza (2015) investigated the effect of debt usage on the performance of small scale manufacturing firms in Nigeria. Data were generated from a total sample of twenty (20) small manufacturing firms randomly selected from the population of study. Applying the regression equation method for data analysis, results confirmed the null hypothesis that there is a negative relationship between debt usage and the value of small manufacturing firms. Likewise, Harwood (2015) conducted an investigation to find out whether the use of debt in a firm's debt structure affects firm performance. The study used a longitudinal research design in collection of data from a target population of 11 commercial banks listed on Nairobi Securities Exchange in Kenya. Data was analyzed using correlation and regression statistics and results show that the use of debt in firms' capital structure, negatively but not significantly affect their performance.

Suleiman and Ahmed (2016) conducted a study on the impact of capital structure on firm's performance in Nigeria. They used a sample of seven (7) building material firms in Nigeria listed on the Nigerian Stock Exchange from 2005-2014. Data were sourced from the firms' financial statements and were analyzed using multiple regression and correlation statistics to determine the level of the impact of capital structure surrogated by short and long term debts on the firms' performance proxied by return on assets. The analyses revealed that both short and long term debts have a significant impact on firm's performance.

Nwude, Itiri, Agbadua and Ude (2016) investigated the impact of debt structure on the performance of Nigerian quoted firms. Annualized panel data, spanning the period, 2001-2012 from 43 firms cutting across different sectorial classifications was used. The study employed three regression estimates; pooled OLS, fixed effects \& random effects to analyze the data collected. Agreeing with pecking order theory, result showed that debt structure has negative and significant impact on the performance of Nigerian quoted firms.

Abdul and Badmus (2017) assessed the relationship between leverage and Return on Assets of Chemicals and Paints firms quoted on the floor of Nigerian Stock Exchange using a sample of three firms randomly chosen from a total of nine firms listed in the sector for a period of ten years, 2000 -2009. Ordinary Least Square (OLS) was used as a method of estimation for the data sourced secondarily from the NSE factbook. Return on Assets (ROA) was used as measure of performance while Equity (EQT) and Debt Ratio (DR) were proxies for capital structure respectively. The study found that capital structure is an important determinant of firm's financial performance and firms that finance with more equity performs better than that of more levered firms. The study further revealed that asset tangibility is an important determinant of financial performance. 
Krishna and Kumar (2018) analyzed the impact of financial leverage measured by debt ratios on the performance of the public sector companies measured by Return on Equity (ROE) and Return on Assets (ROA) respectively. By employing Pearson coefficient of correlation and multiple regression, the results indicate a positive relationship between debt ratios and ROE and a negative relationship between debt ratios and ROA.

Farhan, Iqra and Muhammad (2018) investigated the optimal level of capital structure that firms can adopt to improve their financial performance given the industry dynamics and economic circumstances of the country. Paper used Hausman's specification test on annual data for the period 2005 - 2014 of Karachi Stock Exchange (KSE) 100 index listed securities. Return on assets, return on Equity, and TOBIN's Q were the proxies for financial performance analyzed against financial leverage for the KSE 100 index listed firms. The finding of the paper indicates that capital structure, leverage, interest cover and sales growth are most significant variables impacting firms' profitability.

Ndubuisi, Ifechi and Nweke (2019), examined the relationship between financial leverage and firm financial performance in Nigeria using 80 non-financial firms quoted on the Nigerian Stock Exchange from 2000 to 2015. The total debt to capital ratio, debt to equity ratio, cost of debt, debt to asset ratio and long term debt to capital ratios were proxies for financial leverage. Panel data technique in the form of the pooled regression model, fixed effect model, random effect model, and the marginal model was applied to test hypotheses. The study found earnings per share to be significant and negatively related to the debt to equity ratio and the total debt to total asset measures of financial leverage while the return on equity showed insignificant relationship with the financial leverage measures in Nigeria. The direction of the relationship differs from one variable to the other. It was positive with the total debt to capital ratio and the cost of debt but negative to total debt to asset ratio, long term debt to capital ratios and debt to equity ratio.

Yen, Nhung, Anh and Huong (2019), investigated relationship between capital structure and firm performance focusing on the group of Food and Beverage Companies in Vietnam. The dependent variables were ROA (return on asset), ROE (return on equity) and EPS (earning per share), whereas, independent variables were DA (debt ratio), STA (short term debt ratio), and LTA (long term debt ratio). By using the unbalanced panel data of 605-observation from 61 listed companies, and employing pooled OLS, FEM and REM regression analysis, study found that financial leverage has a strong impact on firm performance, debt ratios significantly and positively affect ROE, and EPS but negatively affect ROA.

Yinusa, Ismail, Yulia and Olawale (2019), examined the impact of capital structure on firm performance in Nigeria. Precisely, the study tested the possibility of non-monotonic relationship between capital structure and firm performance based on the prediction of the agency cost theory of capital structure when firm use debt financing excessively. They used dynamic panel model on panel data of 115 listed non-financial firms in Nigeria. Specifically, the paper utilized the two step generalized method of moments (GMM) estimation method that recognizes the persistence of the dependent variable by including its lag value as an explanatory variable in the regression model. The study found statistical significant relationship between capital structure and firm performance particularly when debt financing is moderately employed. This finding provides evidence of non-monotonic relationship between capital structure and firm performance when firms in Nigeria employed excessive debt financing which impinged on the performance of firms. 


\section{METHODOLOGY}

Empirical Design and Data: The study utilized ex-post facto research design. Accordingly, five manufacturing firms listed on the floor of the Nigerian Stock Exchange (NSE) were first randomly selected and their annual reports and financial statements retrieved. Further, the debt capital profiles as well as performance variables in the respective financial statements were critically examined for uniformity, frequency, and consistency. It was observed that across the five selected firms, only one firm, NASCON Plc., had complete required data with respect to long and short tenured debt, and other relevant performance indicators and so was purposively selected and analytical data generated for the periods 2007-2018. Dependent variables were proxied by the firm's returns on asset (ROA) and returns on equity (ROE), while explanatory variables were proxied by long and short term debt components respectively. Extracted data were subsequently analyzed using computer based multivariate linear regression statistics aided by the Statistical Package for Social Science (SPSS) computer version 20 .

Null Hypotheses: Two null hypotheses were formulated to guide the research as follows:

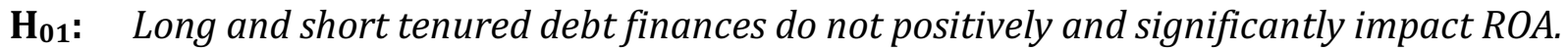
$\mathbf{H}_{02}$ : $\quad$ Long and short tenured debt finances do not positively and significantly impact ROE.

Analytical Econometric Model and Justifications: Inferences from reviewed foreign empirical studies including Zahoor (2015) and Harwood (2015) have shown that the analytical framework and testing procedures employed to measure the effect of debt on firm performance often determine the conclusion thereof. The previous researches have drawn theoretical strength from existing models such as Cobb Douglas among others which proceed from the assumption that changes in the aggregate output of a firm can be explained by changes in the various debt components of the firm's capital structure over a given timeframe. Rather than duplicating in totality the methodology of previous researches, this study modified a more recently employed regression model by Yinusa, et.al, (2019) which captures some factors considered sensitive and relevant to the Nigerian economy in recent time. The study therefore differs from previous studies in three main respects. First, it utilized a model that has been recently modified and used in related study in Nigeria. Secondly, the analytical approach is different. Thirdly, the period covered (2007 - 2018) is unique. By patterning Yinusa, et.al, (2019), the multivariate linear regression models are thus specified:

$$
\begin{aligned}
& \mathrm{ROA}_{\text {it }}=\beta_{0}+\beta_{1} \mathrm{LTD}_{\text {it }}+\beta_{2} \mathrm{STD}_{\text {it }}+\mathrm{e}_{\text {it }} \ldots \ldots \ldots \ldots \ldots \ldots \ldots \ldots \ldots \ldots \ldots \ldots \\
& \mathrm{ROE}_{\text {it }}=\beta_{0}+\beta_{1} \mathrm{LTD}_{\text {it }}+\beta_{2} \mathrm{STD}_{\mathrm{it}}+\mathrm{e}_{\mathrm{it}} \ldots \ldots \ldots \ldots \ldots \ldots \ldots . . .2
\end{aligned}
$$

Where:

$\mathrm{ROA}_{\mathrm{it}}=$ Return On Assets of NASCON Plc over the timeframe

$\mathrm{ROE}_{\text {it }}=$ Return On Equity of NASCON Plc over the timeframe

$\mathrm{LTD}_{\text {it }}=$ Long Term Debt of NASCON Plc over the timeframe

$\mathrm{STD}_{\text {it }}=$ Short Term Debt of NASCON Plc over the timeframe

$\beta_{0} \quad=$ Constant of the regression

$\beta_{1,2}=$ Coefficient of the explanatory variables

$\mathrm{e} \quad=$ Random error term

\section{Regression and Correlation Statistics}

\section{RESULTS AND DISCUSSIONS}

Table (1) and (2) below are summary statistics of the results emanating from the SPSS computer output (See appendix): 


\begin{tabular}{c|ccc|c|c}
\hline \multicolumn{7}{|c}{ Table (1): Coefficients ( @ 95\% Confidence Interval for B) } \\
\hline & $\begin{array}{c}\text { Independent } \\
\text { Variables }\end{array}$ & Constant & Beta (Coeff.) & C & Sig. \\
Dependent & LTD & 49.429 & -1.633 & -0.640 & 0.546 \\
Variable: ROA & STD & \multirow{2}{*}{31.190} & -1.300 & -0.372 & 0.723 \\
Dependent & LTD & \multicolumn{2}{c}{-4.856} & 1.253 & 0.257 \\
Variable: ROE & STD & -4.477 & -1.434 & 0.202 \\
\hline
\end{tabular}

Cursory observations of table 1 results show useful evidence for achieving the study objectives. The constant of the two explanatory variables for ROA is 49.429 and 31.190 for ROE respectively. The values are positive and statistically significant at 95\% confidence level. The constant value is the intercept of the regression line indicating that return on the sampled manufacturing company's assets (ROA) as well as equity (ROE) will be N49.43b and N31.19b if other variables are zeros. On the rate of change in ROA as individually induced by the predictors, the coefficient of LTD is $(-1.633)$ while that of STD is $(-1.300)$. The meaning is that for every one unit increase in LTD and STD over the period of investigation holding other variables constant, ROA decreased by $1.63 \%$ and $1.30 \%$ respectively; an implication that LTD and STD eroded returns on the asset of the sampled manufacturing firm over the period investigated.

Conversely, LTD and STD manifested varying effects on ROE within the defined period. Precisely, LTD enhanced ROE though insignificantly while STD showed depletion. A one percent $(1 \%)$ increase in LTD over the period of study increased ROE by approximately $2.86 \%$ but 1\% increase in STD decreased same by approximately $4.48 \%$. Inferring from the above outcomes, one can justifiably assert that financial leverage effect of debt is possible on manufacturing firms but majorly when long tenured debt is emphasized. The above outcomes agree with traditional signaling theory that submits that debt is a credible signal of the quality of firms and "good-quality" firms are more inclined to issue debt. It is also consistent with previous studies (Jaramillo and Schiantarelli, 1996; Suleiman \& Ahmed, 2016). The findings above are further confirmed using relevant statistics summarized in table 2.

Table 2: Relationship and Variance Statistics

\begin{tabular}{|c|c|c|c|c|c|c|c|}
\hline \multirow[b]{2}{*}{ Pearson Corr. } & \multicolumn{2}{|l|}{ Variables } & \multicolumn{2}{|l|}{ LTD } & \multicolumn{3}{|c|}{ STD } \\
\hline & $\begin{array}{l}\text { ROA } \\
\text { ROE }\end{array}$ & & $\begin{array}{l}-0.917 \\
-0.301\end{array}$ & & \multicolumn{3}{|c|}{-0.913} \\
\hline & Independent Variables & $\mathbf{R}$ & $\mathbf{R}^{2}$ & Adj. $R^{2}$ & $\mathbf{F}$ & F-Sig & DW \\
\hline $\mathrm{H}_{01}$ & LTD, STD & 0.919 & 0.844 & 0.792 & 16.240 & 0.004 & 2.759 \\
\hline $\mathbf{H}_{02}$ & LTD, STD & 0.568 & 0.322 & 0.097 & 1.428 & 0.311 & 2.249 \\
\hline \multicolumn{8}{|c|}{ Dependent Variables: $\mathrm{ROA}\left(\mathrm{H}_{01}\right), \mathrm{ROE}\left(\mathrm{H}_{02}\right)$} \\
\hline \multicolumn{8}{|c|}{ Source: Extracted from SPSS Output in Appendix $1 \& 2$} \\
\hline
\end{tabular}

Verifying for the nature of the relationship between the variables, the Pearson correlation coefficient was applied. Pearson correlation coefficient assumes that the data are normally distributed with the coefficient values ranging between -1 to 1 . Accordingly, the sign of the coefficient determines the direction of the relationship. It could either be negative or positive respectively. From table 2, the coefficient of correlation between ROA and LTD is -0.917 and 0.913 for ROA and STD respectively. Similarly, the coefficient of correlation between ROE and LTD is -0.301 and -0.381 for ROE and STD respectively. The correlation coefficients of -0.917 and -0.913 indicate strong negative relationship between ROA and LTD as well as STD. But the 
correlation coefficients of -0.301 and -0.381 indicate weak negative relationship between ROE and LTD as well as STD.

The multiple correlation coefficient (R) defines the correlation between the predicted and the observed values of the dependent variables. The values for $\mathrm{R}$ range from 0 to 1 . The larger value for $\mathrm{R}$ suggests strong relationship between the predicted and the observed values of the dependent variable. The $\mathrm{R}$ value for $\mathrm{H}_{01}(\mathrm{ROA})$ is 0.919 while that of $\mathrm{H}_{02}(\mathrm{ROE})$ is 0.568 . This indicates that there is a strong relationship between the predicted and the observed values of the dependent variable in $\mathrm{H}_{01}$ but a semi-strong relationship between the predicted and the observed values of the dependent variable in $\mathrm{H}_{02}$. The $\mathrm{R}^{2}$ statistics for $\mathrm{H}_{01}$ is 0.844 and 0.322 for $\mathrm{H}_{02}$ respectively. This implies that $84.4 \%$ of the variations in the dependent variable in model 1 (ROA) is explained by the independent variables in the model. The remaining $15.6 \%$ is due to other factors not accounted for in the model. Similarly, $32.2 \%$ of the variations in the dependent variable in model 2 (ROE) is explained by the independent variables in the model. The remaining $67.8 \%$ is due to other factors outside the model.

\section{Validation of Hypotheses with sig-value \& $t$-Statistics Decision Rule:}

Testing the two hypotheses of this study, the sig \& $t$ statistics were considered. This was to capture the magnitudinal and directional contents of the stated hypotheses. Accordingly, the decision rule was to reject the null hypothesis and accept the alternate hypothesis if the sigvalue is less than 0.05 and the corresponding $t$-value is positive; otherwise, accept the null.

For hypothesis one, the sig-values are (0.546) (0.723)>0.05 while the $t$-values are $(-0.640)(-$ 0.372 ). Based on the above decision rule, $\mathrm{H}_{01}$ was not rejected. Hence the paper submits that long and short tenured debt finances do not positively and significantly impact ROA.

Similarly, the sig-values for hypothesis 2 are (0.257) (0.202) $>0.05$ while the $t$-values are (1.253) (-1.434). Based on the above decision rule, $\mathrm{H}_{01}$ was again not rejected. Hence the paper submits that long and short tenured debt finances do not positively and significantly impact ROE.

\section{CONCLUSION AND RECOMMENDATIONS}

The paper examined the impact of debt finance on corporate performance in Nigeria. Specifically, the study sought to evaluate the impact of long and short tenured debt finances on corporate performance viewed from the prism of firms' returns on both asset and equity respectively. One obvious conclusion arising from the findings of the study is that: although long and short tenured debt finances may not significantly impact positively on ROA and ROE, long tenured debt could slightly enhance corporate performance. This conclusion corroborates Jaramillo and Schiantarelli (1996) who documented that the availability of long-term finance allows manufacturing companies to improve their productivity. If a firm has access to longterm debt finance, it can invest in new capital and equipment which helps to increase productivity. The foregoing conclusion has generated useful recommendations for fasttracking the value added impact of debt finance on corporate performance in Nigeria:

- First, with a negative impact of debt on corporate performance as established, management of manufacturing firms in Nigeria should be cautious in their deployment of debt capital so that the cost of debt does not outweigh its benefits as proposed by the tradeoff theory. To this end, financial managers should be conscious of excessive debt when raising finance; rather, they should source more of equity to better their firms' performances. 
- However, the nature of debt is a major determinant of firm performance. If a firm has access to long-term debt finance, it can invest in new capital and equipment which helps to increase productivity. But inability to access long-term finance can force manufacturing companies to use short-term debt to finance long-term projects. Invariably, this will create mismatches of assets and liabilities and depletes working capital which in turn will negatively affect firm operations. Hence, financial managers of manufacturing firms should design optimum capital structure for long and short tenured debt finances considering the impact of both on corporate performance.

\section{References}

Abdul, J. \& Badmus, O. (2017) “Effect of Leverage on Firm Performance in Nigeria: A Case of Listed Chemicals and Paints Firms in Nigeria", Global Journal of Management and Business Research: Accounting and Auditing 17 (2)(1.0) $14-24$

Akinlo, O. \& Asaolu, T. (2012) "Profitability and Leverage: Evidence from Nigerian Firms" Global Journal of Business Research, 6 (1): 17-25

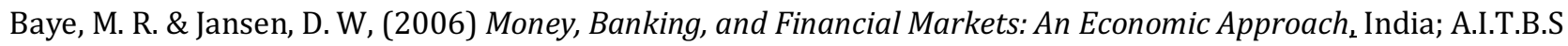
Publishers

Eleje, E. O. \& Modebe, N. J. (2014), "Uncertainty and Corporate Risk Hedging in Nigeria: An Empirical Evidence', Abuja Journal of Banking and Finance, 4 (4), 150-162

Eleje, E. O. (2009), “Global Economic System Recovery: How Far Has Nigeria Gone with the Prevailing Turmoil in Her Financial Market," Journal of the Chartered Institute of Bankers of Nigeria, 5(1)19-25

Eleje, E. O. \& Okafor, F.O. (2010), “Development of Commodity Derivatives Market in Nigeria: An Empirical Assessment", African Journal of Contemporary Issues, 10 (1)1-10

Farhan A., Iqra, A., \& Muhammad, K. (2018), “Financial Leverage and Firms' Performance: Empirical Evidence from KSE-100 Index", Etikonomi, 17 (1) 45 - 56

Gavrea, C., Ilies, L., Stegerean, R. (2011), "Determinants of Organizational Performance: The Case of Romania," Management \& Marketing Challenges for the Knowledge Society, 6, (2), 285-300

Harwood, I. K. (2015), "Effect of Debt on Firms Performance: A Survey of Commercial Banks Listed on Nairobi Securities Exchange” Global Journal of Advanced Research, Vol. 2 (6) 1025-1029

Hashem, S. J. (2015) “An Overview of Organizational Performance Index: Definitions and Measurements” Researchgate DOI: 10.13140/RG.2.1.4298.3849; 1-11

Jorion, P. (1995), Importance of Derivative Securities Markets to Modern Finance, Chicago, Illinois: Irwin

Krishna, K. H., \& Kumar, T.V.V. P. (2018) “Financial Leverage and Firm Performance - An Empirical Study of Select Public Sector Undertakings listed at BSE, India, International Journal of Business and Management Invention (IJBMI) 7(12)(1)30-34

Lawal, B. A., Edwin T. K., Monica W. K., \& Adisa, M. K. (2014), “Effects of Capital Structure on Firm’s Performance: Empirical Study of Manufacturing Companies in Nigeria" Journal of Finance and Investment Analysis, 3(4); 39-57

Lucio, G. (2007) “Introduction to Spot and Derivatives Markets for Commodities and Power, Lombroso: Dipartiments Matermatica DIMAD.Macmillan \& Co

Modigliani, F. \& Miller, M. (1958), "The Cost of Capital, Corporation Finance and the Theory of Investment" American Economic Review, 48: 261-297

Ndubuisi, K., Ifechi, J., \& Nweke, C. J. (2019), "Financial Leverage and Firm Financial Performance in Nigeria: A Panel Data Analysis Approach", Global Journal of Management and Business Research: Finance 19 (4) 12-19

Nwude, C. E., Itiri, I. O., Agbadua, B. O., \& Ude, S. N. (2016) “The Impact of Debt Structure on Firm Performance; Empirical Evidence from Nigerian Quoted Firms" Asian Economic and Financial Review 6 (11): 647-660.

Onimisi, A. N. (2010), "Effect of Capital Structure On The Performance Of Quoted Manufacturing Firms In Nigeria" M.Sc Thesis Submitted to the School of Postgraduate Studies of Ahmadu Bello University, Zaria

Osuji, C. C. (2012), "Impact of Capital Structure on the Financial Performance of Nigerian Firms” Arabian Journal of Business and Management Review, 1(12):43-58 
Pandey (2001), “Capital Structure and Firm Characteristics: Evidence from an Emerging Market”, Working Paper, Indian Institute of Management, Ahmedabad

Pandey, I. M. (2006), Financial Management" New Edition, New Delhi, Vikas Publishing House

Przepiorka, W. \& Berger, J. (2018), "Signaling Theory Evolving: Signals and Signs of Trustworthiness in Social Exchange", ResearchGate, Retrieved Online 20/12/19 via https://www.researchgate.net/publication/319648214

Rajkumar, P. (2014), "Impact of Financial Leverage on Financial Performance: Special Reference to John Keells Holdings plc in Sri Lanka" Scientific Research Journal (SCIRJ), II (II):15-20

Suleiman M. I., \& Ahmed H. (2016), "The Impact of Capital Structure on Firm Performance in Nigeria: A Study of Nigerian Building Material Industry", Proceedings of 2nd International Conference on Management, Economics and Social Sciences Held on 19th - 20th November in Dubai, U.A.E

Tufano, P. (1996) “Who Manages Risk? An Empirical Examination of Risk Management Practices in the Gold Mining Industry", Journal of Finance (4), 1097-112

Yen T. H. D., Nhung, T. H. B., Anh, T. H. D., \& Huong T. N. (2019), “The Impact Of Capital Structure On Firm Performance: Empirical Evidence From Listed Food And Beverage Companies In Vietnam" International Journal of Economics, Commerce and Management, VII (2) 567-577

Yinusa, O. G., Ismail, A., Yulia, R. \& Olawale, L. S. (2019), “Capital Structure and Firm Performance in Nigeria”, African Journal of Economic Review, VII (I) 31-56

Zahoor, H. J., Huma, R., Bader, A., \& Muhammad, F. N. (2015), Effect of Financial Leverage on Performance of the Firms: Empirical Evidence from Pakistan", SPOUDAI Journal of Economics and Business, 65(1) (2): 87-95 


\section{APPENDIX 1: REGRESSION ONE: EFFECT OF LONG AND SHORT TERM DEBT ON ROA}

\begin{tabular}{|l|r|r|r|}
\hline & Descriptive Statistics & \multicolumn{1}{c|}{ N } \\
\hline ROA & Mean & Std. Deviation & 12 \\
LTD & 35.9478 & 10.52410 & 12 \\
STD & 602670.0000 & 375813.83894 & 12 \\
\hline
\end{tabular}

\begin{tabular}{|c|c|c|c|c|}
\hline \multicolumn{5}{|c|}{ Correlations } \\
\hline & & ROA & LTD & STD \\
\hline \multirow{3}{*}{ Pearson Correlation } & ROA & 1.000 & -.917 & -.913 \\
\hline & LTD & -.917 & 1.000 & .984 \\
\hline & STD & -.913 & .984 & 1.000 \\
\hline \multirow{3}{*}{ Sig. (1-tailed) } & ROA & & .000 & .000 \\
\hline & LTD & .000 & & .000 \\
\hline & STD & .000 & .000 & \\
\hline & ROA & 12 & 12 & 12 \\
\hline \multirow[t]{2}{*}{$\mathrm{N}$} & LTD & 12 & 12 & 12 \\
\hline & STD & 12 & 12 & 12 \\
\hline
\end{tabular}

Model Summaryb

\begin{tabular}{|c|c|c|c|c|c|c|c|c|c|c|}
\hline \multirow[t]{2}{*}{ Model } & \multirow[t]{2}{*}{$\mathrm{R}$} & \multirow[t]{2}{*}{ R Square } & \multirow{2}{*}{$\begin{array}{l}\text { Adjusted R } \\
\text { Square }\end{array}$} & \multirow{2}{*}{$\begin{array}{l}\text { Std. Error of } \\
\text { the Estimate }\end{array}$} & \multicolumn{5}{|c|}{ Change Statistics } & \multirow[t]{2}{*}{ Durbin-Watson } \\
\hline & & & & & $\begin{array}{l}\text { R Square } \\
\text { Change }\end{array}$ & $\begin{array}{c}\mathrm{F} \\
\text { Change }\end{array}$ & df1 & df2 & $\begin{array}{c}\text { Sig. F } \\
\text { Change }\end{array}$ & \\
\hline 1 & $.919^{a}$ & .844 & .792 & 4.79856 & .844 & 16.240 & 2 & 6 & .004 & 2.7 \\
\hline
\end{tabular}

a. Predictors: (Constant), STD, LTD

b. Dependent Variable: ROA

\begin{tabular}{|c|c|c|c|c|c|c|}
\hline \multicolumn{7}{|c|}{ ANOVAa } \\
\hline Model & & Sum of Squares & $\mathrm{df}$ & Mean Square & $\mathrm{F}$ & Sig. \\
\hline \multirow{3}{*}{1} & Regression & 747.897 & 2 & 373.949 & 16.240 & $.004^{b}$ \\
\hline & Residual & 138.157 & 6 & 23.026 & & \\
\hline & Total & 886.054 & 8 & & & \\
\hline
\end{tabular}

a. Dependent Variable: ROA

b. Predictors: (Constant), STD, LTD

\begin{tabular}{|c|c|c|c|c|c|c|c|c|c|c|c|}
\hline \multirow{2}{*}{\multicolumn{2}{|c|}{ Model }} & \multicolumn{2}{|c|}{$\begin{array}{c}\text { Unstandardized } \\
\text { Coefficients }\end{array}$} & \multirow{2}{*}{$\begin{array}{c}\begin{array}{c}\text { Standardized } \\
\text { Coefficients }\end{array} \\
\text { Beta }\end{array}$} & \multirow[t]{2}{*}{$\mathrm{t}$} & \multirow[t]{2}{*}{ Sig. } & \multicolumn{2}{|c|}{$\begin{array}{l}95.0 \% \text { Confidence } \\
\text { Interval for B }\end{array}$} & \multicolumn{3}{|c|}{ Correlations } \\
\hline & & $\mathrm{B}$ & $\begin{array}{l}\text { Std. } \\
\text { Error }\end{array}$ & & & & $\begin{array}{l}\text { Lower } \\
\text { Bound }\end{array}$ & $\begin{array}{l}\text { Upper } \\
\text { Bound }\end{array}$ & $\begin{array}{l}\text { Zero- } \\
\text { order }\end{array}$ & Partial & Part \\
\hline \multirow{3}{*}{1} & (Constant) & 49.429 & 6.215 & & 7.953 & .000 & 34.221 & 64.636 & & & \\
\hline & LTD & $-1.633 \mathrm{E}-005$ & .000 & -.583 & -.640 & .546 & .000 & .000 & -.917 & -.253 & -.103 \\
\hline & STD & $-1.300 \mathrm{E}-006$ & .000 & -.339 & -.372 & .723 & .000 & .000 & -.913 & -.150 & -.060 \\
\hline
\end{tabular}

a. Dependent Variable: ROA 


\section{APPENDIX 2: REGRESSION TWO: EFFECT OF LONG AND SHORT TERM DEBT ON ROE}

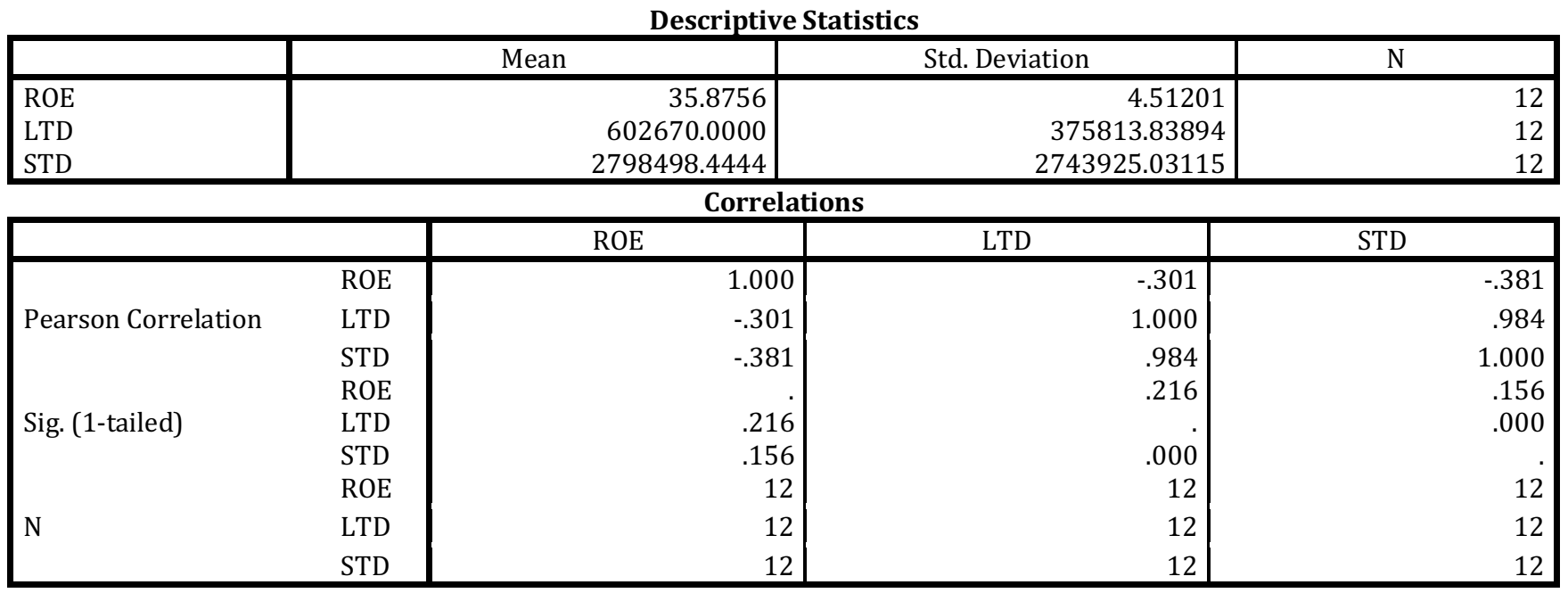

Model Summaryb

\begin{tabular}{|c|c|c|c|c|c|c|c|c|c|c|}
\hline \multirow[t]{2}{*}{ Model } & \multirow[t]{2}{*}{$\mathrm{R}$} & \multirow{2}{*}{$\begin{array}{c}\mathrm{R} \\
\text { Square }\end{array}$} & \multirow{2}{*}{$\begin{array}{l}\text { Adjusted R } \\
\text { Square }\end{array}$} & \multirow{2}{*}{$\begin{array}{l}\text { Std. Error of the } \\
\text { Estimate }\end{array}$} & \multicolumn{5}{|c|}{ Change Statistics } & \multirow{2}{*}{$\begin{array}{l}\text { Durbin- } \\
\text { Watson }\end{array}$} \\
\hline & & & & & $\begin{array}{l}\text { R Square } \\
\text { Change }\end{array}$ & $\begin{array}{c}\mathrm{F} \\
\text { Change }\end{array}$ & df1 & df2 & $\begin{array}{c}\text { Sig. F } \\
\text { Change }\end{array}$ & \\
\hline 1 & $.568^{\mathrm{a}}$ & .322 & .097 & 4.28852 & .322 & 1.428 & 2 & 6 & .311 & \\
\hline
\end{tabular}

a. Predictors: (Constant), STD, LTD

b. Dependent Variable: ROE

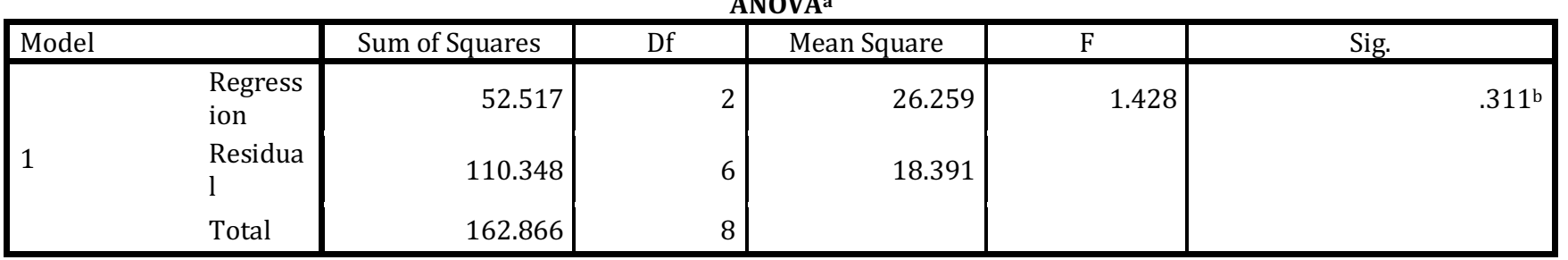

a. Dependent Variable: ROE

b. Predictors: (Constant), STD, LTD

Coefficients ${ }^{\mathrm{a}}$

\begin{tabular}{|c|c|c|c|c|c|c|c|c|c|c|c|}
\hline \multirow{2}{*}{\multicolumn{2}{|c|}{ Model }} & \multicolumn{2}{|c|}{$\begin{array}{l}\text { Unstandardized } \\
\text { Coefficients }\end{array}$} & \multirow{2}{*}{$\begin{array}{c}\begin{array}{c}\text { Standardize } \\
\mathrm{d} \\
\text { Coefficients }\end{array} \\
\text { Beta }\end{array}$} & \multirow[t]{2}{*}{$\mathrm{t}$} & \multirow[t]{2}{*}{ Sig. } & \multicolumn{4}{|c|}{ 95.0\% Confidence Interval for B } & \multirow{2}{*}{$\begin{array}{c}\text { Correlations } \\
\text { Part }\end{array}$} \\
\hline & & B & $\begin{array}{l}\text { Std. } \\
\text { Error }\end{array}$ & & & & $\begin{array}{l}\text { Lower } \\
\text { Bound }\end{array}$ & $\begin{array}{l}\text { Upper } \\
\text { Bound }\end{array}$ & $\begin{array}{l}\text { Zero- } \\
\text { order }\end{array}$ & Partial & \\
\hline \multirow{3}{*}{1} & (Constant) & 31.190 & 5.555 & & 5.615 & .001 & 17.599 & 44.781 & & & \\
\hline & LTD & $2.856 \mathrm{E}-005$ & .000 & 2.379 & 1.253 & .257 & .000 & .000 & -.301 & .455 & .421 \\
\hline & STD & $\begin{array}{r}-4.477 \mathrm{E}- \\
006\end{array}$ & .000 & -2.723 & -1.434 & .202 & .000 & .000 & -.381 & -.505 & -.482 \\
\hline
\end{tabular}

a. Dependent Variable: ROE 